\title{
Identifikasi dan Perbedaan Karakteristik Kompetensi Audit: Auditor Pemerintah Ditinjau dari Pengalaman dan Gender
}

\author{
Indira Januarti \\ Program Studi Akuntansi FEB Universitas Diponegoro Semarang \\ Jl. Prof. Soedharto, SH. Tembalang, Semarang, Jawa Tengah \\ Email:Indira_ppa@yahoo.com
}

\begin{abstract}
$B P K$ auditors need competence to support the role of $C P C$ in achieving good corporate governance and the increasing complexity of tasks to be completed. Auditor who worked in the BPK is not only men but also many women involved, but it also held a variety of experiences. The existence of gender differences and the experience will certainly give a different emphasis on the competence of the audit. Therefore, the purpose of this study was to examine: (1) what are the characteristics of competence audit used by auditors BPK. (2) difference in the characteristics of audit competencies held by the auditor viewed from the experience and gender.
\end{abstract}

Sample research is BPK auditor in Jakarta and Semarang. Samples can be received and processed the data number of 186 respondents. Analysis tools using different test $t$-test. The results demonstrate skills / competencies which non-technical characteristics of psychology (responsibility) to be the first priority. Men prefer the responsibility (traits psychology) while women prefer the independent (decision strategy). Based on the obtained results that male gender prefers to think in a rational than women. While technical and non-technical competence did not differ between men and women. Respondents experienced and inexperienced differ only on the ability of thinking and strategic decision-making.

Keywords: characteristics of competence, experience, gender

\section{Pendahuluan}

Seorang auditor dalam menjalankan tugasnya tidak hanya untuk kepentingan klien, tetapi juga untuk kepentingan berbagai pihak yang menggunakan laporan keuangan auditan. Oleh sebab itu untuk mempertahankan kepercayaan atas laporan keuangan auditan yang dihasilkannya dibutuhkan kompetensi dalam bidang audit. Auditor sebagai ujung tombak dari pelaksanaan kegiatan audit semestinya didukung dengan independensi, kemampuan, kemauan dan pengalaman kerja yang memadai dalam audit. Kemampuan, kemauan dan pengalaman kerja mencerminkan kompetensi yang diharapkan dapat memberikan hasil kerja sesuai dengan misi yang diemban. Menurut Choo dan Trotman (1991) pengalaman dan pengetahuan merupakan faktor yang penting dalam pemberian pendapat.

Auditor dalam melakukan tugas audit hampir selalu dihadapkan pada beragam tugas yang komplek. Keberagaman tugas tersebut menuntut auditor untuk selalu meng- update pengetahuannya, agar auditor mempunyai kompetensi untuk menyelesaikan tugasnya dengan baik. Hal tersebut sesuai dengan standar audit yang mengharuskan seorang auditor untuk memiliki kompetensi dan independesi ketika melakukan audit. Tan dan Libby (1997) mengatakan bahwa keahlian audit terdiri dari tacit managerial dan pengetahuan khusus. Kompetensi dalam bidang audit harus selalu ditingkatkan oleh auditor agar dapat mencapai karakteristik audit yang ideal. Oleh sebab itu identifikasi karakteristik kompetensi dalam audit harus selalu dilakukan untuk mengetahui gambaran mengenai karakteristik yang

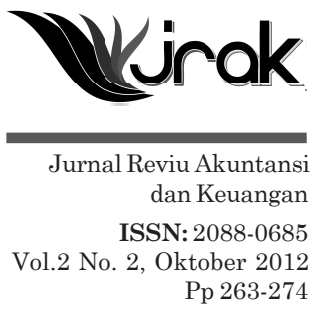


Identifikasi dan

Perbedaan

Karakteristik... dibutuhkan. Setelah diketahui karakteristik yang dibutuhkan, maka akan dapat didesain bentuk pelatihan yang dapat mendukung perbaikan kualitas audit.

Beberapa penelitian tentang kompetensi audit telah dilakukan, diantaranya oleh Abdolmohammadi dan Shantheau (1992), Libby dan Tan (1994), Murtanto dan Gudono (1999), Mayangsari (2003). Dari berbagai penelitian tersebut dihasilkan kategori yang mendukung kompetensi, diantaranya: pengetahuan, ciri-ciri psikologis, kemampuan berpikir, strategi penentuan keputusan, analisis tugas (Abdolmohammadi dan Shanteau 1992). Sedangkan hasil penelitian Murtanto dan Gudono (1999) menambahkan satu kategori, yaitu karakteristik ketrampilan interpersonal. Murtanto dan Gudono (1999) menyatakan bahwa faktor pengetahuan kognitif merupakan faktor yang sangat penting dalam mempengaruhi kompetensi audit. Selain itu ciri-ciri psikologis dan pengetahuan merupakan komponen yang memiliki nilai tinggi dalam model kompetensi.

Ada hubungan yang erat antara kompetensi dan usia ketika menilai suatu kualitas kerja. Adanya persepsi yang menyatakan bahwa pekerja yang tua mempunyai pengalaman, penilaian, etika kerja yang kuat, dan komitmen terhadap kualitas. Sebaliknya mereka dipandang tidak fleksibel dan sering menolak teknologi baru (Robins dan Judge 2007). Usia bisa dianggap sebagai pengalaman kerja, sehingga mereka yang berusia tua bisa menduduki jabatan yang lebih tinggi karena dianggap berpengalaman. Menurut Tan dan Libby (1997) ada perbedaan komponen pengetahuan manajerial, pengetahuan teknikal dan kemampuan dalam memecahkan masalah antara auditor dengan supervisor. Selain perbedaan pengalaman karena usia, persepsi kompetensi individu dapat dibedakan berdasarkan gender. Perbedaan gender diantara pria dan wanita dibentuk oleh suatu proses yang sangat panjang. Pembentukan perbedaan tersebut dapat disebabkan oleh beberapa hal misalnya, melalui sosialisasi, budaya yang berlaku serta kebiasaankebiasaan yang ada. Pendekatan sosialisasi gender menyatakan bahwa pria dan wanita membawa perbedaan nilai dan perlakuan dalam pekerjaannya. Perbedaan ini disebabkan karena pria dan wanita mengembangkan bidang peminatan, keputusan dan praktik yang berbeda yang berhubungan dengan pekerjaannya. Pria dan wanita merespon secara berbeda tentang reward dan cost. Pria akan mencari kesuksesan kompetitif dan bila perlu melanggar aturan untuk mencapainya, sedangkan wanita lebih menekankan untuk melakukan tugasnya dengan baik dan lebih mementingkan harmonisasi dalam relasi pekerjaan. Wanita lebih condong taat pada peraturan dan kurang toleran dengan individu yang melanggar aturan (Ameen, et al. 1996).

Auditor Badan Pemeriksa Keuangan (BPK) sebagai auditor Pemerintah juga tidak lepas dari tuntutan untuk meningkatkan kompetensinya dalam rangka mewujudkan transparansi dan akuntabilitas keuangan negara. Badan Pemeriksa Keuangan (BPK) sebagai akuntan pemerintah mempunyai peranan yang penting dengan dikeluarkannya UU 17/2003 tentang Keuangan Negara, UU no 1/2004 tentang Perbendaharaan Negara, UU no 15/2004 tentang Pemeriksaan Pengelolaan dan Tanggungjawab Keuangan Negara, dan UU 32/2004 tentang Pemerintahan Daerah. Dalam UU 15/2004 tersebut BPK mempunyai fungsi dan wewenang untuk memeriksa pengelolaan dan tanggung jawab keuangan negara yang dilakukan oleh pemerintah pusat, pemerintah daerah, lembaga negara lainnya, Bank Indonesia, BUMN, BUMD, badan layanan umum dan lembaga atau badan lain yang mengelola keuangan negara.

Penelitian yang mengidentifikasi karakteristik kompetensi dalam audit masih sedikit (Abdolmohammadi dan Shanteau 1992; Libby dan Luft 1993; Libby dan Tan 1994; Murtanto dan Gudono 1999). Semua penelitian tersebut menggunakan obyek auditor pada kantor Akuntan Publik, sedangkan untuk auditor Pemerintah belum dilakukan, oleh sebab itu dalam penelitian ini mencoba untuk mengidentifikasi karakteristik kompetensi dalam bidang audit yang dimiliki oleh auditor BPK dibedakan dari pengalaman dan gender. 
Penggunaan auditor BPK untuk mendukung peran BPK dalam mewujudkan good corporate governance dan dengan semakin kompleksnya tugas yang harus diselesaikan, maka auditor BPK harus mengetahui kompetensi apa saja yang harus dimiliki. Auditor yang bekerja di BPK tidak hanya pria tetapi juga banyak melibatkan wanita, selain itu pengalaman yang dimiliki juga beragam. Adanya perbedaan gender dan pengalaman tentunya akan memberikan penekanan yang berbeda terhadap kompetensi audit. Oleh sebab itu tujuan dari penelitian ini adalah untuk menguji: (1) Karakteristik kompetensi audit apa saja yang digunakan oleh auditor BPK. (2) Perbedaan karakteristik kompetensi audit (jumlah pengetahuan, ciri-ciri psychologi, kemampuan berpikir, strategi keputusan, analisis tugas, karakteristik lainnya) yang dimiliki oleh auditor dilihat dari pengalaman dan gender.

Penelitian mengenai identifikasi karakteristik kompetensi dalam audit perlu dilakukan untuk mencapai tujuan audit yang efektif dan efisien dan untuk meningkatkan kualitas audit. Oleh sebab itu penelitian ini mencoba untuk mengidentifikasi karakteristik kompetensi audit pada auditor pemerintah yang dibedakan dari pengalaman dan gender. Adapun manfaat penelitian ini adalah: (1) Dapat memberikan masukan kepada BPK dalam mendesain bentuk pelatihan auditor untuk meningkatkan kompetensi dalam audit. (2) Dapat memberikan gambaran mengenai kompetensi audit yang harus dipersiapkan oleh dunia pendidikan, khususnya jurusan akuntansi sebagai penghasil calon auditor. (3) Menambah topik penelitian yang terkait dengan karakteristik kompetensi dalam bidang audit, khususnya pada auditor pemerintah.

\section{Pengembangan Hipotesis}

Dalam melakukan audit, auditor dituntut untuk mempunyai kemampuan, tidak hanya pengetahuan tetapi juga ciri-ciri psikologi supaya bisa dikatakan ahli dan mereka harus meningkatkan dan mempertahankan image ke publik (Shanteau 1993). Sesuai dengan theory of expert competence (Shanteau 1993) model penelitian ini menggunakan model kompetensi yang dikembangkan oleh Abdolmohammadi dan Shanteau (1992) dan juga digunakan oleh Murtanto dan Gudono (1999), dimana kompetensi auditor dikelompokkan menjadi: (1) Komponen pengetahuan dengan kategori pengetahuan terhadap kenyataan-kenyataan, proses, dan prosedur-prosedur. (2) Ciri-ciri psikologis dengan kategori ciri-ciri kepribadian diri. (3) Kemampuan berpikir dengan kategori kemampuan untuk memperoleh dan memproses informasi. (4) Strategi penentuan keputusan dengan kategori strategi untuk membantu pembuatan keputusan. (5) Analisis tugas dengan kategori penilaian terhadap kesulitan tugas.

Untuk menentukan apakah karakteristik kompetensi dalam audit itu penting, dan apakah perbedaan pengalaman serta gender menyebabkan perbedaan fokus atas kompetensi yang dibutuhkan dalam audit. Abdolmohammadi dan Shanteau (1992) menemukan bukti bahwa manajer/partner lebih banyak fokus pada penentuan, kewajaran dan pertimbangan yang baik, sedangkan mahasiswa cenderung lebih fokus pada obyektivitas, percaya diri dan pertanggung jawaban. Karakteristik kognitif yang dianggap penting baik oleh manajer/ partner maupun mahasiswa sama, yaitu pengetahuan, pencarian fakta, dan pengalaman. Manajer/ partner lebih banyak menggunakan beragam tahapan strategi dalam membuat keputusan, sedangkan mereka yang belum berpengalaman hanya menggunakan satu tahapan. Karakteristik tugas akan dikerjakan dengan baik untuk tugas pengklasifikasian dibandingkan prediksi. Dalam membuat keputusan pendekatan kognitif lebih menekankan pada pengetahuan dan memori, dimana keduanya saling melengkapi (Shanteau 1993).

Pendekatan sosialisasi gender (gender sosialization approach) dari Ameen, et al.(1996) disebutkan bahwa pria dan wanita merespon secara berbeda tentang reward dan cost. Pria akan mencari kesuksesan kompetitif dan bila perlu melanggar 
Identifikasi dan

Perbedaan

Karakteristik... 266 aturan untuk mencapainya. Sedangkan wanita lebih menekankan pada melakukan tugasnya dengan baik dan lebih mementingkan harmonisasi dalam relasi pekerjaan. Wanita lebih condong taat pada peraturan dan kurang toleran dengan individu yang melanggar aturan.

Berdasarkan uraian di atas maka hipotesis yang akan diuji dalam penelitian ini adalah:

H1a: Ada perbedaan jumlah pengetahuan antara auditor yang berpengalaman dan tidak berpengalaman.

H1b: Ada perbedaan ciri-ciri psychologi antara auditor yang berpengalaman dan tidak berpengalaman

H1c: Ada perbedaan kemampuan berpikir antara auditor yang berpengalaman dan tidak berpengalaman

H1d: Ada perbedaan strategi keputusan antara auditor yang berpengalaman dan tidak berpengalaman

H1e: Ada perbedaan analisis tugas antara auditor yang berpengalaman dan tidak berpengalaman

H1f: Ada perbedaan karakteristik lainnya antara auditor yang berpengalaman dan tidak berpengalaman

H2a: Ada perbedaan jumlah pengetahuan antara auditor pria dan wanita.

H2b: Ada perbedaan ciri-ciri psychologi antara auditor pria dan wanita.

H2c: Ada perbedaan kemampuan berpikir antara auditor pria dan wanita.

$\mathrm{H} 2 \mathrm{~d}$ : Ada perbedaan strategi keputusan antara auditor pria dan wanita.

H2e: Ada perbedaan analisis tugas antara auditor pria dan wanita.

H2f: Ada perbedaan karakteristik lainnya antara auditor pria dan wanita.

\section{METODE PENELITIAN}

\section{Populasi dan Sampel}

Populasi dalam penelitian ini adalah auditor BPK se-Jawa. Sedangkan sampel yang diambil auditor BPK di Jakarta dan Semarang. Kuesioner yang dibagi sebanyak 200 eksemplar dengan rincian BPK Jakarta dan Semarang masing-masing 100 eksemplar. Kuesioner yang diterima sebanyak 186, sehingga respon rate 93\%. Semua kuesioner dapat dianalisis.

\section{Definisi Operasional dan Ukuran Variabel.}

Variabel dalam penelitian ini meliputi karakteristik kompetensi audit, pengalaman dan gender. Karakteristik kompetensi yaitu kemampuan yang harus dimiliki oleh seorang auditor. Karakteristik kompetensi menggunakan model yang digunakan oleh Abdolmohammadi dan Shanteau (1992), Murtanto dan Gudono (1999) yang dikelompokkan menjadi:

1. Komponen pengetahuan, yaitu merupakan komponen penting dalam suatu keahlian. Komponen pengetahuan meliputi pengetahuan umum dan khusus, berpengalaman, mendapat informasi yang cukup dan relevan, selalu berusaha untuk tahu, mempunyai visi.

2. Ciri-ciri psikologis, yaitu merupakan self-presentation-image attribute of experts seperti: rasa percaya diri, bertanggung jawab, ketekunan, ulet dan energik, cerdik dan kreatif, adaptasi, kejujuran, kecekatan.

3. Kemampuan berpikir, yaitu merupakan kemampuan untuk mengakumulasi dan mengolah informasi, seperti: berpikir analitis dan logika, cerdas, tanggap dan berusaha menyelesaikan masalah, berpikir cepat dan terperinci. 
4. Strategi penentuan keputusan baik formal maupun informal yang akan membantu dalam membuat keputusan yang sistematis dan membantu keahlian dalam mengatasi keterbatasan manusia, seperti: independen dan obyektif, integritas.

5. Analisis tugas yang banyak dipengaruhi oleh pengalaman-pengalaman audit dan analisis tugas ini akan mempunyai pengaruh terhadap penentuan keputusan, seperti: ketelitian, tegas, profesional dalam tugas, ketrampilan teknis, menggunakan metode analisis, kecermatan, loyalitas dan idealisme.

Masing-masing indikator diukur dengan skala Likert 5 poin $(1=$ kurang penting dan $5=$ sangat penting). Ketika responden menjawab dengan kecenderungan 1, maka di simpulkan indikator tersebut tidak penting dalam audit.

Untuk variabel pengalaman di ukur dengan lamanya bekerja (tahun). Auditor dikatakan berpengalaman apabila masa kerjanya $>4$ tahun (Choo dan Trotman 1991). Auditor yang berpengalaman diberi simbol 2 dan yang tidak berpengalaman diberi simbol 1. Variabel gender diberi simbol 1 untuk pria dan 2 untuk wanita.

\section{Alat Analisis.}

Menggunakan tabel frekuensi untuk mengidentifikasi karakteristik kompetensi audit. Setiap jawaban responden ditabulasi, kemudian diurutkan berdasarkan peringkat yang terbanyak dianggap yang paling penting. Untuk menjawab hipotesis 1 dan 2 digunakan uji beda $t$-test. Apabila tingkat signifikansi $\alpha>5 \%$, maka disimpulkan bahwa hipotesis tidak dapat diterima (ditolak).

\section{HASIL DAN PEMBAHASAN}

\section{Deskripsi Responden}

Berdasarkan tabel 1 terlihat statistik deskripsi dari responden meliputi: karakteristik pengetahuan, ciri-ciri psikologi, kemampuan pikir, strategi keputusan Karateristik pribadi.

\begin{tabular}{lrrrrrr}
\hline \multicolumn{7}{c}{ Statistics } \\
\hline & jpength & ciri pski & pikir & strategi & analis tgs & pribadi \\
\hline $\mathrm{N} \quad$ Valid & 186 & 186 & 186 & 186 & 186 & 186 \\
\multicolumn{1}{c}{ Missing } & 0 & 0 & 0 & 0 & 0 & 0 \\
Rata-rata & 21.47 & 30.85 & 17.42 & 9.27 & 30.94 & 17.30 \\
Median & 22.00 & 31.00 & 17.00 & 10.00 & 31.00 & 17.00 \\
Minimum & 11 & 20 & 11 & 5 & 16 & 10 \\
Maximum & 25 & 35 & 20 & 10 & 35 & 20 \\
\hline
\end{tabular}

Tabel 1

Tabel 2 memperlihatkan jumlah kuesioner yang dapat diolah sebanyak 186 responden, yang terdiri dari 95 orang pria dan 91 wanita. Berdasarkan pengalamannya diperoleh responden yang berpengalaman (> 4 tahun) sebanyak 111 res- $^{-}$ ponden dan yang belum berpengalaman sebanyak 75 responden. Untuk masingmasing kriteria kompetensi terlihat bahwa nilai rata-rata pria memperlihatkan hasil yang lebih besar dibandingkan wanita meskipun selisihnya tidak banyak. Pria mempunyai keahlian non teknis (ciri-ciri psikologi) yang sedikit lebih tinggi dibandingkan wanita, sedangkan keahlian non teknis lainnya sama (kemampuan berpikir, strategi penentuan keputusan dan kompetensi lainnya). Pria mempunyai keahlian teknis (analisis tugas) yang lebih tinggi dibandingkan wanita, sedangkan komponen pengetahuan tidak berbeda antara pria dan wanita. 


\begin{tabular}{l} 
Identifikasi \\
dan \\
Perbedaan \\
Karakteristik... \\
$\mathbf{2 6 8}$ \\
\hline
\end{tabular}

Tabel 2

Perbandingan Ratarata berdasarkan Gender, Pengalaman

Tabel 3

Gambaran Umum Responden

\begin{tabular}{lccrrrr}
\hline \multicolumn{1}{c}{ Keterangan } & \multicolumn{3}{c}{ gender } & \multicolumn{3}{c}{ pengalaman } \\
\hline & sampel & kode & rata-rata & sampel & kode & rata-rata \\
\hline Pengetahuan & 95 & $\mathrm{~L}$ & 21.76 & 75 & Tdk & 21.73 \\
\hline Ciri psychologi & 91 & $\mathrm{P}$ & 21.18 & 111 & Ya & 21.30 \\
\hline & 95 & $\mathrm{~L}$ & 31.12 & 75 & $\mathrm{Tdk}$ & 31.29 \\
\hline kemampuan & 91 & $\mathrm{P}$ & 30.57 & 111 & Ya & 30.55 \\
\hline berpikir & 95 & $\mathrm{~L}$ & 17.67 & 75 & Tdk & 17.73 \\
\hline Strategi keputusan & 95 & $\mathrm{~L}$ & 9.34 & 75 & $\mathrm{Tdk}$ & 9.43 \\
\hline & 91 & $\mathrm{P}$ & 9.21 & 111 & Ya & 9.17 \\
\hline analisis tugas & 95 & $\mathrm{~L}$ & 31.17 & 75 & $\mathrm{Tdk}$ & 31.36 \\
\hline & 91 & $\mathrm{P}$ & 30.70 & 111 & Ya & 30.66 \\
\hline Karakteristik & 95 & $\mathrm{~L}$ & 17.35 & 75 & Tdk & 17.43 \\
\hline lainnya & 91 & $\mathrm{P}$ & 17.24 & 111 & Ya & 17.21 \\
\hline
\end{tabular}

Rata-rata kriteria kompetensi responden yang belum berpengalaman justru lebih tinggi dibandingkan rata-rata responden yang berpengalaman. Auditor yang belum berpengalaman mempunyai keahlian non teknis (ciri-ciri psikologi) dan keahlian teknis (analisis tugas) yang lebih tinggi dibandingkan auditor yang berpengalaman. Dengan demikian dapat dikatakan bahwa responden yang belum berpengalaman memandang ciri-ciri psikologi dan analisis tugas menjadi kompetensi yang lebih penting dibandingkan kompetensi lainnya.

Berdasarkan tabel 3 terlihat bahwa umur minimum dari responden adalah 20 tahun dan maksimum 54 tahun dengan nilai rata-rata 32 tahun 5 bulan. Nilai rata-rata tersebut menunjukkan bahwa reponden kebanyakan sudah berpengalaman. Jumlah pelatihan selama satu tahun terakhir yang diikuti oleh responden terbanyak 8 kali dan ada yang tidak ikut pelatihan sama sekali. Responden yang belum melakukan audit ada 1 karena baru masuk 6 bulan, sedangkan jumlah audit yang paling banyak dilakukan adalah 50 kali penugasan.

\begin{tabular}{lcccc}
\hline & N & Minimum & Maximum & Rata-rata \\
\hline Usia & 186 & 20 & 54 & 32.05 \\
jml plthan & 186 & 0 & 8 & 2.69 \\
jml audit & 186 & 0 & 50 & 11.88 \\
Valid N (listwise) & 186 & & & \\
\hline
\end{tabular}

Berdasarkan tabel 4 terlihat bahwa responden secara keseluruhan menganggap ciri-ciri psikologi (tanggungjawab) menjadi prioritas pertama disusul strategi penentuan keputusan (integritas dan independen), analisis tugas (profesional dalam tugas), ciri kompetensi lainnya (komunikatif), jumlah pengetahuan (informasi yang cukup) dan kemampuan berpikir (tanggap dan berusaha). Hasil penelitian ini mendukung penelitian Murtanto dan Gudono (1999) yang memberikan bukti bahwa ciri-ciri psikologi memberikan nilai yang paling tinggi dalam model kompetensi. Hasil penelitian ini juga mendukung penelitian dari Shanteau dan Abdolmohammadi(1992) yang memberikan bukti bahwa ciri-ciri psikologi dan strategi penentuan keputusan sebagai kompetensi yang diprioritaskan.

Pria lebih mengutamakan tanggungjawab (ciri-ciri psikologi), integritas (strategi keputusan), profesional dalam tugas (analisis tugas), dapat bekerja sama (ciri kompetensi lainnya), pengetahuan umum dan khusus (jumlah pengetahuan) dan 
tanggap serta berusaha (kemampuan berpikir). Untuk wanita lebih mengutamakan independen (strategi keputusan), tanggungjawab (ciri-ciri psikologi), profesional dalam tugas (analisis tugas), komunikatif (ciri-ciri kompetensi lainnya), informasi yang cukup (jumlah pengetahuan), dan berpikir analitis dengan logika (kemampuan berpikir). Dengan melihat hasil tersebut dapat disimpulkan bahwa pandangan kompetensi menurut pria dan wanita sama, yang utama yaitu bertanggungjawab, mempunyai integritas dan independen.

Responden yang berpengalaman lebih mengutamakan bertanggungjawab (ciriciri psikologi), integritas (strategi keputusan), komunikatif (ciri kompetensi lainnya), profesional dalam tugas (analisis tugas), pengetahuan umum dan khusus (jumlah pengetahuan), tanggap dan berusaha (kemampuan berpikir). Responden yang belum berpengalaman lebih mengutamakan independen (strategi keputusan), profesional dalam tugas (analisis tugas), bertanggungjawab (ciri-ciri psikologi), informasi yang cukup (jumlah pengetahuan), dapat bekerja sama (ciri-ciri kompetensi lainnya), berpikir analitis dengan logika (kemampuan berpikir). Dengan demikian dapat disimpulkan bahwa karakteristik kompetensi menurut auditor yang berpengalaman dan tidak berpengalaman juga sama, yaitu memprioritaskan tanggungjawab, mempunyai integritas, independen dan obyektif.

Berdasarkan penjelasan di atas dapat disimpulkan bahwa kemampuan berpikir menjadi kriteria keahlian non teknis terakhir yang dipertimbangkan oleh responden, baik dilihat dari gender, pengalaman maupun secara total. Sedangkan ciri-ciri psikologi lebih dipertimbangkan baik oleh pria maupun responden yang berpengalaman khususnya tanggungjawab terhadap tugas. Untuk wanita dan responden yang berpengalaman lebih mengutamakan strategi keputusan dalam hal ini untuk bersikap independen. Responden baik dilihat dari gender maupun perbedaan pengalaman lebih mengutamakan keahlian non teknis dibandingkan keahlian teknis.

\begin{tabular}{|c|c|c|c|c|}
\hline & \multicolumn{2}{|c|}{ Gender } & \multicolumn{2}{|c|}{ Pengalaman } \\
\hline & pria & wanita & ya & blm \\
\hline \multicolumn{5}{|l|}{ Jumlah Pengetahuan } \\
\hline Pengetahuan umum dan khusus & 12 & 10 & 9 & 16 \\
\hline Pengalaman & 28 & 28 & 25 & 29 \\
\hline Informasi yang cukup & 8 & 13 & 10 & 13 \\
\hline Berusaha untuk tahu & 23 & 26 & 28 & 20 \\
\hline Mempunyai visi & 27 & 27 & 26 & 28 \\
\hline \multicolumn{5}{|l|}{ Ciri-Ciri Psychologi } \\
\hline Percaya diri & 11 & 11 & 13 & 9 \\
\hline Bertanggungjawab & 2 & 1 & 1 & 3 \\
\hline Tekun dan ulet & 15 & 16 & 15 & 17 \\
\hline Cerdik dan kreatif & 21 & 24 & 23 & 24 \\
\hline Adaptasi & 26 & 25 & 27 & 26 \\
\hline Kejujuran & 4 & 3 & 3 & 7 \\
\hline Cekatan & 23 & 19 & 20 & 22 \\
\hline \multicolumn{5}{|l|}{ Kemampuan Berpikir } \\
\hline Berpikir analitis dengan logika & 10 & 15 & 21 & 24 \\
\hline Cerdas & 24 & 22 & 22 & 27 \\
\hline Tanggap dan berusaha & 13 & 14 & 12 & 15 \\
\hline Berpikir cepat dan terperinci & 17 & 20 & 19 & 18 \\
\hline \multicolumn{5}{|l|}{ Strategi keputusan } \\
\hline Independen & 1 & 7 & 6 & 2 \\
\hline Integritas & 3 & 2 & 2 & 4 \\
\hline \multicolumn{5}{|l|}{ Analisis Tugas } \\
\hline Teliti & 6 & 8 & 7 & 8 \\
\hline Tegas & 18 & 18 & 18 & 21 \\
\hline Profesional dalam tugas & 5 & 4 & 5 & 6 \\
\hline Ketrampilan teknis & 20 & 17 & 17 & 19 \\
\hline
\end{tabular}

Tabel 4

Ringkasan Peringkat Karakteristik Kompetensi 


\begin{tabular}{l}
$\begin{array}{l}\text { Identifikasi } \\
\text { dan }\end{array}$ \\
Perbedaan \\
Karakteristik... \\
$\mathbf{2 7 0}$ \\
\hline
\end{tabular}

Tabel 5

Pengujian hipotesis berdasarkan gender Independent Samples Test

\begin{tabular}{lrrrr}
\hline & \multicolumn{2}{c}{ Gender } & \multicolumn{2}{c}{ Pengalaman } \\
\hline Menggunakan metode analisa & pria & wanita & ya & blm \\
\hline Cermat & 19 & 23 & 16 & 11 \\
\hline Loyal dan idealis & 16 & 12 & 14 & 14 \\
\hline Ciri kompetensi lainnya & 14 & 9 & 11 & 12 \\
\hline Komunikatif & \multicolumn{5}{c}{} & \\
\hline Dapat bekerja sama & 7 & 6 & 4 & 10 \\
\hline Relasional & 9 & 5 & 8 & 5 \\
\hline
\end{tabular}

\section{Hasil dan Pembahasan Hipotesis}

Berdasarkan tabel 5 menunjukkan bahwa hanya kemampuan berpikir yang secara statistik signifikan pada $\alpha=10 \%(0,107)$, sedangkan kriteria kompetensi lainnya tidak signifikan secara statistik. Dengan demikian hipotesis yang diterima hanya 1c, yaitu kemampuan berpikir pria berbeda dengan wanita. Pria memandang kemampuan berpikir sebagai hal yang lebih penting dibandingkan dengan wanita. Hal ini didukung dengan bukti seperti yang terlihat di tabel 2 bahwa rata-rata kemampuan berpikir pria lebih tinggi dibanding wanita.

Hipotesis 1a, b, d, e, f yaitu jumlah pengetahuan, ciri-ciri psikologi, strategi penentuan, analisis tugas dan ciri-ciri kompetensi lainnya secara statistik tidak signifikan sehingga disimpulkan untuk variabel-variabel tersebut tidak ada perbedaan antara pria dengan wanita. Hal ini sesuai dengan pendekatan struktural, yang menyatakan bahwa baik pria maupun wanita menggunakan kompetensinya secara sama dalam merespon tugas yang diberikan (Ameen, et al.1996). Hasil ini sesuai pendapat Robbin dan Judge (2007) yang menyatakan bahwa tidak ada beda antara pria dan wanita yang secara konsisten dalam kemampuan menyelesaikan masalah, ketrampilan analitis, sosialisasi maupun dorongan belajar .

\begin{tabular}{|c|c|c|c|c|c|c|c|c|c|c|}
\hline & & \multicolumn{4}{|c|}{$\begin{array}{l}\text { Levene's Test } \\
\text { for Equality of } \\
\text { Variances }\end{array}$} & \multicolumn{5}{|c|}{ t-test for Equality of Rata-ratas } \\
\hline & & \multirow[b]{2}{*}{$\mathbf{F}$} & \multirow[b]{2}{*}{ Sig. } & \multirow[b]{2}{*}{$\mathbf{t}$} & \multirow[b]{2}{*}{ df } & \multirow{2}{*}{$\begin{array}{l}\text { Sig. (2- } \\
\text { tailed) }\end{array}$} & \multirow{2}{*}{$\begin{array}{l}\text { Rata-rata } \\
\text { Difference }\end{array}$} & \multirow{2}{*}{$\begin{array}{l}\text { Std. Error } \\
\text { Difference }\end{array}$} & \multicolumn{2}{|c|}{$\begin{array}{l}\text { 95\% Confidence } \\
\text { Interval of the } \\
\text { Difference }\end{array}$} \\
\hline & & & & & & & & & Lower & Upper \\
\hline \multirow{2}{*}{ jpength } & $\begin{array}{l}\text { Equal variances } \\
\text { assumed }\end{array}$ & 5.511 & .020 & 1.517 & 184 & .131 & .582 & .384 & -.175 & 1.339 \\
\hline & $\begin{array}{l}\text { Equal variances not } \\
\text { assumed }\end{array}$ & & & 1.524 & $\begin{array}{r}178.49 \\
2\end{array}$ & .129 & .582 & .382 & -.171 & 1.336 \\
\hline \multirow[t]{2}{*}{ ciri pski } & $\begin{array}{l}\text { Equal variances } \\
\text { assumed }\end{array}$ & 1.095 & .297 & 1.115 & 184 & .266 & .544 & .488 & -.419 & 1.508 \\
\hline & $\begin{array}{l}\text { Equal variances not } \\
\text { assumed }\end{array}$ & & & 1.117 & $\begin{array}{r}182.92 \\
8 \\
\end{array}$ & .265 & .544 & .487 & -.417 & 1.506 \\
\hline \multirow[t]{2}{*}{ pikir } & $\begin{array}{l}\text { Equal variances } \\
\text { assumed }\end{array}$ & .005 & .944 & 1.618 & 184 & .107 & .509 & .314 & -.111 & 1.129 \\
\hline & $\begin{array}{l}\text { Equal variances not } \\
\text { assumed }\end{array}$ & & & 1.619 & $\begin{array}{r}183.75 \\
9 \\
\end{array}$ & .107 & .509 & .314 & -.111 & 1.129 \\
\hline \multirow[t]{2}{*}{ strategi } & $\begin{array}{l}\text { Equal variances } \\
\text { assumed }\end{array}$ & .920 & .339 & .877 & 184 & .382 & .128 & .146 & -.160 & .416 \\
\hline & $\begin{array}{l}\text { Equal variances not } \\
\text { assumed }\end{array}$ & & & .877 & $\begin{array}{r}183.25 \\
1\end{array}$ & .382 & .128 & .146 & -.160 & .416 \\
\hline \multirow[t]{2}{*}{$\begin{array}{l}\text { analis } \\
\text { tgs }\end{array}$} & $\begin{array}{l}\text { Equal variances } \\
\text { assumed }\end{array}$ & 1.201 & .275 & .895 & 184 & .372 & .465 & .520 & -.561 & 1.491 \\
\hline & $\begin{array}{l}\text { Equal variances not } \\
\text { assumed }\end{array}$ & & & .897 & $\begin{array}{r}183.06 \\
3\end{array}$ & .371 & .465 & .519 & -.558 & 1.489 \\
\hline \multirow[t]{2}{*}{ pribadi } & $\begin{array}{l}\text { Equal variances } \\
\text { assumed }\end{array}$ & 4.649 & .032 & .392 & 184 & .695 & .106 & .269 & -.426 & .637 \\
\hline & $\begin{array}{l}\text { Equal variances not } \\
\text { assumed }\end{array}$ & & & .394 & $\begin{array}{r}179.72 \\
9\end{array}$ & .694 & .106 & .268 & -.424 & .635 \\
\hline
\end{tabular}


Berdasarkan tabel 6 menunjukkan hanya kemampuan berpikir $(0,108)$ dan strategis penentuan keputusan $(0,73)$ yang secara statistik signifikan pada $\alpha=$ $10 \%$. Dengan demikian dapat disimpulkan bahwa hipotesis yang diterima hanya $2 \mathrm{c}$ dan $2 \mathrm{~d}$ yaitu kemampuan berpikir dan strategi penentuan keputusan antara responden yang berpengalaman berbeda dengan responden yang belum berpengalaman. Sesuai dengan tabel 2 bahwa kemampuan berpikir dan strategi penentuan keputusan responden yang belum berpengalaman lebih tinggi dibanding responden yang berpengalaman. Responden yang belum berpengalaman memandang kedua kompetensi tersebut lebih tinggi dibandingkan responden yang berpengalaman. Hal ini bisa disebabkan kemampuan berpikir responden yang belum berpengalaman belum begitu terasah karena pengalaman mereka belum lama dalam bekerja $(<4$ tahun).

Hipotesis 2a, b, e dan f yaitu jumlah pengetahuan, ciri-ciri psychologi, analisis tugas dan ciri kompetensi lainnya secara statistik tidak signifikan, sehingga untuk semua variabel-variabel tersebut tidak ada perbedaan antara responden yang berpengalaman dan tidak berpengalaman.

\begin{tabular}{|c|c|c|c|c|c|c|c|c|c|c|}
\hline & & \multicolumn{2}{|c|}{$\begin{array}{l}\text { Levene's Test } \\
\text { for Equality of } \\
\text { Variances }\end{array}$} & \multicolumn{7}{|c|}{ t-test for Equality of Rata-ratas } \\
\hline & & \multirow[b]{2}{*}{$\mathbf{F}$} & \multirow[b]{2}{*}{ Sig. } & \multirow[b]{2}{*}{$\mathbf{t}$} & \multirow[b]{2}{*}{ df } & \multirow{2}{*}{$\begin{array}{l}\text { Sig. (2- } \\
\text { tailed) }\end{array}$} & \multirow{2}{*}{$\begin{array}{c}\text { Rata-rata } \\
\text { Differenc } \\
\text { e }\end{array}$} & \multirow{2}{*}{$\begin{array}{c}\text { Std. } \\
\text { Error } \\
\text { Differenc } \\
\text { e }\end{array}$} & \multicolumn{2}{|c|}{$\begin{array}{l}\text { 95\% Confidence } \\
\text { Interval of the } \\
\text { Difference }\end{array}$} \\
\hline & & & & & & & & & Lower & Upper \\
\hline \multirow{2}{*}{ jpength } & $\begin{array}{l}\text { Equal variances } \\
\text { assumed }\end{array}$ & .309 & .579 & 1.112 & 184 & .268 & .436 & .392 & -.337 & 1.210 \\
\hline & $\begin{array}{l}\text { Equal variances } \\
\text { not assumed }\end{array}$ & & & 1.124 & 164.583 & .263 & .436 & .388 & -.330 & 1.202 \\
\hline \multirow[t]{2}{*}{ ciri pski } & $\begin{array}{l}\text { Equal variances } \\
\text { assumed }\end{array}$ & .000 & .999 & 1.498 & 184 & .136 & .744 & .496 & -.236 & 1.723 \\
\hline & $\begin{array}{l}\text { Equal variances } \\
\text { not assumed }\end{array}$ & & & 1.496 & 157.916 & .137 & .744 & .497 & -.238 & 1.726 \\
\hline \multirow[t]{2}{*}{ pikir } & $\begin{array}{l}\text { Equal variances } \\
\text { assumed }\end{array}$ & .146 & .703 & 1.614 & 184 & .108 & .517 & .320 & -.115 & 1.149 \\
\hline & $\begin{array}{l}\text { Equal variances } \\
\text { not assumed }\end{array}$ & & & 1.603 & 155.093 & .111 & .517 & .323 & -.120 & 1.154 \\
\hline \multirow[t]{2}{*}{ strategi } & $\begin{array}{l}\text { Equal variances } \\
\text { assumed }\end{array}$ & 5.222 & .023 & 1.728 & 184 & .086 & .255 & .148 & -.036 & .547 \\
\hline & $\begin{array}{l}\text { Equal variances } \\
\text { not assumed }\end{array}$ & & & 1.803 & 178.605 & .073 & .255 & .142 & -.024 & .535 \\
\hline \multirow[t]{2}{*}{$\begin{array}{l}\text { analis } \\
\text { tgs }\end{array}$} & $\begin{array}{l}\text { Equal variances } \\
\text { assumed }\end{array}$ & .420 & .518 & 1.329 & 184 & .186 & .702 & .528 & -.340 & 1.745 \\
\hline & $\begin{array}{l}\text { Equal variances } \\
\text { not assumed }\end{array}$ & & & 1.359 & 170.619 & .176 & .702 & .517 & -.318 & 1.722 \\
\hline \multirow[t]{2}{*}{ pribadi } & $\begin{array}{l}\text { Equal variances } \\
\text { assumed }\end{array}$ & .008 & .927 & .801 & 184 & .424 & .219 & .274 & -.321 & .760 \\
\hline & $\begin{array}{l}\text { Equal variances } \\
\text { not assumed }\end{array}$ & & & .808 & 164.090 & .420 & .219 & .271 & -.317 & .755 \\
\hline
\end{tabular}

\section{SIMPULAN DAN SARAN}

Dalam penelitian ini diperoleh hasil keahlian/kompetensi non teknis yaitu ciri-ciri psychologi (tanggungjawab) menjadi prioritas pertama disusul strategi penentuan keputusan (integritas dan independen), analisis tugas (profesional dalam tugas), ciri kompetensi lainnya (komunikatif), jumlah pengetahuan (informasi yang cukup) dan kemampuan berpikir (tanggap dan berusaha). Pria lebih mengutamakan tanggungjawab (ciri-ciri psikologi), integritas (strategi keputusan), profesional
Tabel 6

Pengujian hipotesis berdasar pengalaman Independent Samples Test 
Identifikasi

dan

Perbedaan

Karakteristik...

272 dalam tugas (analisis tugas), dapat bekerja sama (ciri kompetensi lainnya), pengetahuan umum dan khusus (jumlah pengetahuan) dan tanggap serta berusaha (kemampuan berpikir). Sedangkan wanita lebih mengutamakan independen (strategi keputusan), tanggungjawab (ciri-ciri psikologi), profesional dalam tugas (analisis tugas), komunikatif (ciri-ciri kompetensi lainnya), informasi yang cukup (jumlah pengetahuan), dan berpikir analitis dengan logika (kemampuan berpikir).

Berdasarkan gender diperoleh hasil bahwa kemampuan berpikir antara pria dan wanita berbeda. Pria lebih mengutamakan berpikir secara rasional dibandingkan wanita. Sedangkan kompetensi teknis (jumlah pengetahuan dan analisis tugas), kompetensi non teknis (ciri-ciri psikologi, strategi pembuatan keputusan, kompetensi lainnya) tidak berbeda antara pria dan wanita. Hal ini mendukung aspek kultural, dimana respon yang lakukan baik oleh pria maupun wanita tidak berbeda.

Perbedaan antara repsonden yang berpengalaman dan tidak berpengalaman hanya pada kemampuan berpikir dan strategi pengambilan keputusan. Responden yang belum berpengalaman lebih mengutamakan kedua variabel tersebut dibandingkan variabel lainnya. Jumlah pengetahuan, ciri-ciri psikologi, analisis tugas dan kompetensi lainnya tidak berbeda antara responden yang berpengalaman dan tidak berpengalaman.

Saran untuk penelitian mendatang dapat menambah variabel tekanan tugas, motivasi atau variabel lainnya untuk dapat memperkaya hasil penelitian.

\section{DAFTAR PUSTAKA}

Abdel Khalik, A.R., and Solomon,I. 1988. Research Opportunities in Auditing: The Second Decade. Sarasota: American Accounting Association.

Abdolmohammadi, M., and Wright, A.1987. "An Examination of the Effects of $E_{X^{-}}$ perience and Task Complexity on Audit Judgments." The Accounting Review, Vol. I, XII, No.1,1-13.

Abdolmohammadi, M.J.,dan J. Shanteau. 1992. "Personal Attributes of Experts Auditors." Organizational Behavior and Human Decision Process, 53 (november) 158-172.

Ameen, JC. Gulfrey dan Mc Millan JJ. 1996." Gender Differences in Determining the Ethical Sensitivity of Future Accounting Profesionals." Journal of Business Ethics, vol. 15.

Ashton, A.H. 1991." Experience and Error Frequency Knowledge as Potential Determinants of Audit Expertise." The Accounting Review, April, 218-239.

Bonner, S.E., and B.L.Lewis. 1990." Determinants of Auditor Expertise." Journal of Accouting Research, (suplement), 1-20.

Choo, Freddle, and Ken T.Trotman. 1991. "The Relationship Beween Knowledge Structure and Judgements for Experienced and Inexperienced Auditors." The Accounting Review, July, 464-485.

Digabriele, James A. 2008. "An Emperical Investigation of the Relevent Skill of Forensic Accountans." Journal of Education for Business, 331-338.

Gibbins, M. 1984. "Proposition About the Psychology of Professional Judgment in Public Accounting." Journal of Accounting Research, vol. 22, 103-125.

Goodson, J.R., G.W. McGee, and A. Seers.1992. "Giving Appropriate Performance Feedback to Managers: An Empirical Test of Content and Outcomes." The Journal of Business Communication, vol. 19(4), 329-342.

Libby, R., and H.T. Tan. 1994. "Modeling Determinants of Auditing Expertise." Accounting Organization and Society, 701-716.

Libby, R., and J. Luft. 1993. "Determinants of Judgment Performance in Accounting Settings: Ability, Knowledge, Motivation, and Environment." Accounting Organization and Society, Vol. 18, No.5, 425-450. 
Mayangsari, S. 2003. "Pengaruh Keahlian Audit dan Independensi terhadap Pendapat Audit: Sebuah Kuasi Eksperimen." Jurnal Riset Akuntansi Indonesia, Volume 6, No. 1, Januari, 1-22.

Murtanto, dan Gudono.1999. "Identifikasi karakteristik-Karakteristik Keahlian Audit: Profesi Akuntan Publik di Indonesia." Jurnal Riset Akuntansi Indonesia, Volume 2, No. 1 Januari, 37-52.

Nizarul, A., Trisni, H., dan Liliek,P.2007. "Pengaruh Kompetensi dan Independensi Terhadap Kualitas Audit dengan Etika Auditor sebagai Variabel Moderasi." Simposium Nasional Akuntansi X. Makasar: Ikatan Akuntan Indonesia Kompartemen Akuntan Pendidik, 1-26.

Radtke, R.R. 2000. "The Effect of Gender and Setting on Accountants' Ethically Sensitive Decisions." Journal of Business Ethics.

Robbins, S.P., and Judge,T.A.2007. Organizational Behavior. 12th ed. Pearson Education,Inc.

Rustiana.2003. "Studi Empiris Novice Accountant: Tinjauan Gender." Jurnal Studi Bisnis, vol. 1 no. 2.

Shanteau, J. "Discussion of Expertise in Auditing." Auditing: A Journal of Practice and Theory, 1993: vol 12. Suplement.

Tan, Hun-Ton, and Robert Libby. "Tacit Managerial versus Technical Knowledge as Determinants of Audit expertise in The Field." Journal of Accounting Research (Spring), 1997: 97-113. 
